\title{
Synthesis, structure and properties of $\mathrm{N}$-R-amides and hydrazides of 2-[4-R-5-(3'-methylxanthine-7'-yl)-1,2,4-triazole-3-ylthio]acetic acid
}

\author{
A. S. Hotsulia \\ Zaporizhzhia State Medical University, Ukraine
}

Introduction. Heterocyclic compounds are the foundation on which the creation of medicines is successfully carried out. One such system is 1,2,4-triazole and 3-methylxanthine. These heterocycles are characterized by wide range of biological properties, along with low toxicity.

The purpose of this work was to synthesize and investigate the properties of $\mathrm{N}$-R-amides and hydrazides 2-[4-R-5-(3'-methylxanthine7'-yl)-1,2,4-triazole-3-ylthio]acetic acid $\left(\mathrm{R}=\mathrm{CH}_{3}, \mathrm{C}_{2} \mathrm{H}_{5}, \mathrm{C}_{6} \mathrm{H}_{5}\right)$ when changing the conditions of the chemical process.

Methods and results. As initial key reagents we used 7'-((3-thio-4-R-4H-1,2,4-triazole-5-yl)methyl)-3'-methylxanthine and ethers of 2-[4-R-5-((3'-methylxanthine-7'-yl)methyl)-1,2,4-triazole-3-ylthio]acetic acid, which were prepared according to known procedures from available raw materials. In the course of studies, it was found that when heated in ethanol the corresponding primary or secondary alkylamines (methylamine, ethylamine, monoethanolamine, diethylamine) or ammonia solution from prop-1-yl 2-[4-R-5-((3'-methylxanthine7'-yl)methyl)-1,2,4-triazole-3-ylthio]ethanoate, then the corresponding amidated derivatives of 2-[4-R-5-((3'-methylxanthine-7'-yl)methyl)1,2,4-triazole-3-ylthio]acetic acid are created. The corresponding amides were obtained by reacting 7'-((3-thio-4-R-4H-1,2,4-triazol-5-yl) methyl)-3'-methylxanthine with 2-chloroacetamide in a high yield sodium hydroxide medium. Hydrazides of 2-[4-R-5-((3'-methylxanthine-7'yl)methyl)-1,2,4-triazole-3-ylthio]-ethane acid are synthesized by the interaction of the corresponding esters of 2-[4-R-5-((3'-methylxanthine7'-yl)methyl)-1,2,4-triazole-3-ylthio]acetic acid with an aqueous hydrazine hydrate solution in ethanol. The structure of the obtained compounds is confirmed by the data of elemental analysis, ${ }^{1} \mathrm{H}$ NMR spectroscopy, IR-spectrophotometry. Individuality was established using thin-layer chromatography and chromatography-mass spectrometry. For synthesized compounds, preliminary screening was performed using the PASS On-line ${ }^{\circledR}$ software and molecular docking. The optimal methods for the preparation hydrazides and amides of 2-[4-R-5-((3'-methylxanthine-7'-yl)methyl)-1,2,4-triazole-3-ylthio]ethane acid were developed. The production of amides in two alternative pathways using the starting thiol and the ester, derived from it, was studied: it was established that the interaction of the starting thiol with 2-chloroacetamide runs with a larger yield of the reaction product in comparison with the reaction of the corresponding ester with ammonia. The results of physical-chemical analysis of synthesized compounds was interpreted. This preliminary assessment of the possible manifestation of anti-inflammatory activity was given. The probability of manifestation of this type of activity was not high.

Conclusions. 19 amides and 3 hydrazide of 2-[4-R-5-((3'-methylxanthine-7'-yl)methyl)-1,2,4-triazole-3-ylthio]ethane acid were obtained with high yields and purity, their structure was proven and properties were investigated.

\section{Синтез, будова та властивості N-R-амідів 2-[4-R-5-(3'-метилксантин-7'-іл)-1,2,4-тріазол-3-ілтіо]ацетатної кислоти}

\section{А. С. Гоцуля}

Гетероциклічні сполуки - фундамент, на якому успішно відбувається створення лікарських засобів. Одними з таких систем є 1,2,4-тріазол і 3-метилксантин. Похідним цих гетероциклічних систем притаманний широкий спектр біологічних властивостей $\mathrm{i}$ невисока токсичність.

Мета роботи - синтез і дослідження властивостей N-R-амідів і гідразидів 2-[4-R-5-(3'-метилксантин-7'-іл)-1,2,4-тріазол-3-ілтіо]ацетатної кислоти $\left(\mathrm{R}=\mathrm{CH}_{3}, \mathrm{C}_{2} \mathrm{H}_{5}, \mathrm{C}_{6} \mathrm{H}_{5}\right)$ при зміні умов перебігу хімічного процесу.

Матеріали та методи. Як ключові вихідні реагенти використали 7'-((3-тіо-4-R-4H-1,2,4-тріазол-5-іл)метил)-3'-метилксантин та есріри 2-[4-R-5-((3'-метилксантин-7'-іл)метил)-1,2,4-тріазол-3-ілтіо]етанової кислоти, які отримали за відомими методиками 3 доступної сировини.

Результати. Встановили, що при нагріванні в етанолі відповідних первинних чи вторинних алкіламінів (метиламін, етиламін, моноетаноламін, діетиламін), розчину амоніаку з проп-1-іл-2-[4-R-5-((3'-метилксантин-7'-іл)метил)-1,2,4-тріазол-3-ілтіо]етаноатом утворюються відповідні амідовані похідні 2-[4-R-5-((3'-метилксантин-7'-іл)метил)-1,2,4-тріазол-3-ілтіо]етанової кислоти. Взаємодією 7'-((3-тіо-4-R-4H-1,2,4-тріазол-5-іл)метил)-3'-метил-ксантину з 2-хлорацетамідом у середовищі розчину натрій гідроксиду з високими виходами одержали відповідні аміди. Гідразиди 2-[4-R-5-((3'-метилксантин-7'-іл)метил)-1,2,4-тріазол-3-ілтіо]етанової кислоти синтезовані взаємодією відповідних естерів 2-[4-R-5-((3'-метилксантин-7'-іл)метил)-1,2,4-тріазол-3-ілтіо]етанової кислоти з водним розчином гідразин гідрату в середовищі етанолу. Структура сполук підтверджена даними елементного аналізу, спектроскопії ${ }^{1} \mathrm{H}$ ЯМР,

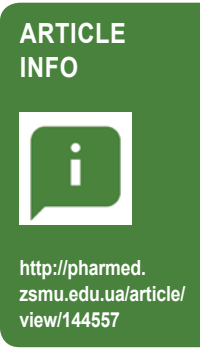

UDC: $547.857 .4^{\prime} 792 ' 292.057 .022 .03$

DOI: 10.14739/2409-2932.2018.3.144557

Current issues in pharmacy and medicine: science and practice 2018; 11 (3), 254-259

Key words: 1,2,4-triazole, 3-methylxanthine, physical-chemical properties, molecular docking.

E-mail: andrey.goculya@gmail.com

Received: 31.07 .2018 // Revised: 16.08 .2018 // Accepted: 29.08.2018 
ІЧ-спектрофотометрії. Індивідуальність встановили за допомогою тонкошарової хроматографії та хромато-мас-спектрометрії. Для синтезованих сполук виконали попередній розрахунковий скринінг за допомогою програмного продукту PASS On-line ${ }^{\circledR}$ та молекулярного докінгу. Розробили оптимальні методи одержання гідразидів та амідів 2-[4-R-5-((3'-метилксантин-7'-іл)метил)-1,2,4-тріазол-3-ілтіо] етанової кислоти. Дослідили одержання амідів за двома альтернативними шляхами з використанням вихідного тіолу та отриманого на його основі естеру: встановлено, що взаємодією вихідного тіолу з 2-хлорацетамідом перебігає з більшим виходом продукту реакції порівняно з реакцією взаємодії відповідного естеру з амоніаком. Інтерпретували результати фрізико-хімічного аналізу синтезованих сполук. Здійснили попереднє оцінювання можливої появи протизапальної активності - імовірність не висока.

Висновки. 3 високими виходами та чистотою одержали 19 амідів і 3 гідразиди 2-[4-R-5-((3'-метилксантин-7'-іл)метил)-1,2,4-тріазол-3-ілтіо]етанової кислоти, довели їх структуру та дослідили властивості.

Ключові слова: 1,2,4-тріазол, 3-метилксантин, фізико-хімічні властивості, молекулярний докінг.

Актуальні питання фармацевтичної і медичної науки та практики. - 2018. - Т. 11, № 3(28). - С. 254-259

Синтез, строение и свойства N-R-амидов 2-[4-R-5-(3'-метилксантин-7'-ил)-1,2,4-триазол-3-илтио]ацетатной кислоты

\section{А. С. Гоцуля}

Гетероциклические соединения - фундамент, на котором успешно происходит создание лекарственных средств. Одними из таких систем являются 1,2,4-триазол и 3-метилксантин. Производным данных гетероциклов присущ широкий спектр биологических свойств наряду с невысокой токсичностью.

Цель работы - синтез и исследование свойств N-R-амидов и гидразидов 2-[4-R-5-(3'-метилксантин-7'-ил)-1,2,4-триазол-3-илтио] ацетатной кислоты $\left(\mathrm{R}=\mathrm{CH}_{3}, \mathrm{C}_{2} \mathrm{H}_{5}, \mathrm{C}_{6} \mathrm{H}_{5}\right)$ при изменении условий протекания химического процесса.

Материалы и методы. В качестве ключевых исходных реагентов использованы 7'-((3-тио-4-R-4H-1,2,4-триазол-5-ил)метил)-3'-метилксантин и эфиры 2-[4-R-5-((3'-метилксантин-7'-ил)метил)-1,2,4-триазол-3-илтио]-этановой кислоты, которые получены по известным методикам из доступного сырья.

Результаты. В ходе исследований установлено, что при нагревании в этаноле соответствующих первичных или вторичных алкиламинов (метиламин, этиламин, моноэтаноламин, диэтиламин) или раствора аммиака с проп-1-ил-2-[4-R-5-((3'-метилксантин-7'-ил)метил)-1,2,4-триазол-3-илтио]этаноатом образуются соответствующие амиды 2-[4-R-5-((3'-метилксантин-7'-ил)метил)-1,2,4-триазол-3-илтио]этановой кислоты. Взаимодействием 7'-((3-тио-4-R-4H-1,2,4-триазол-5-ил)метил)-3'-метил-ксантина c 2-хлорацетамидом в среде раствора натрий гидроксида с высокими выходами получены соответствующие амиды. Гидразиды 2-[4-R-5-((3'-метилксантин-7'-ил)метил)-1,2,4-триазол-3-илтио]этановой кислоты синтезированы взаимодействием соответствующих эфиров 2-[4-R-5-((3'-метилксантин-7'-ил)метил)-1,2,4-триазол-3-илтио]этановой кислоты с водным раствором гидразин гидрата в среде этанола. Структура полученных соединений подтверждена данными элементного анализа, спектроскопии ${ }^{1} \mathrm{H}$ ЯМР, ИК-спектрофотометрии. Индивидуальность установлена с помощью тонкослойной хроматографии и хромато-масс-спектрометрии. Для синтезированных соединений проведен предварительный расчетный скрининг с помощью программного продукта PASS On-line ${ }^{\circledR}$ и молекулярного докинга. Разработаны оптимальные методы получения гидразидов и амидов 2-[4-R-5-((3'-метилксантин-7'-ил)метил)-1,2,4-триазол-3-илтио]этановой кислоты. Исследовано получение амидов по двум альтернативными путям с использованием исходного тиола и полученного на его основе эфира: установлено, что взаимодействием исходного тиола с 2-хлорацетамидом протекает с большим выходом продукта реакции по сравнению с реакцией взаимодействия соответствующего эфира с аммиаком. Интерпретированы результаты физико-химического анализа синтезированных соединений. Дана предварительная оценка возможного проявления противовоспалительной активности - вероятность невысокая.

Выводы. С высокими выходами и чистотой получены 19 амидов и 3 гидразида 2-[4-R-5-((3'-метилксантин-7'-ил)метил)-1,2,4-триазол-3-илтио]этановой кислоты, доказана их структура и исследованы свойства.

Ключевые слова: 1,2,4-триазол, 3-метилксантин, физико-химические свойства, молекулярный докинг.

Актуальные вопросы фрармацевтической и медицинской науки и практики. - 2018. - Т. 11, № 3(28). - С. 254-259

\section{Introduction}

One of the important tasks of modern pharmaceutical science is the search for new biologically active substances that have high efficiency and low toxicity [1,6-8]. In our time there is a considerable interest in the derivatives of various heterocyclic systems [3]. There are no exceptions to 1,2,4-triazole and 3-methylxanthine, which are important synthones for the synthesis of various biologically active compounds on their basis $[4,5,10]$. Objective reasons for the search for a number of these derivatives are the high synthetic and pharmacological potential of these synthones. Our attention was drawn to previously unexplored amides and hydrazides of 2-[4-R-5-((3'-methylxanthin-7'-yl)-1,2,4-triazole-3-ylthio] acetic acid $[2,4-6,9]$.

\section{The purpose}

The purpose of the work is to synthesize new amides and hydrazides of 2-[4-R-5-(3'-methylxanthine-7'-yl)-1,2,4triazole-3-ylthio]acetic acid and investigate their properties.

\section{Materials and methods}

As the key starting reagents we used alkyl-2-(4-R-5-(3'methylxanthine-7'-yl)methyl)-4H-1,2,4-triazole-3-ylthio) ethanoates, which were obtained according to well-known techniques from available raw materials. In the course of studies, it was found that when heated in ethanol, the corresponding amines (ammonia, methylamine, ethylamine, monoethanolamine, diethanolamine) with prop-1-yl ester 
Table 1. Characterization data of synthesized compounds<smiles>[R]N(C)C(=O)CSc1nnc(Cn2cnc3c2c(=O)[nH]c(=O)n3C)n1[R]</smiles>

\begin{tabular}{|c|c|c|c|c|c|c|}
\hline Compound & $\mathbf{R}$ & $R_{1}$ & $\mathbf{R}_{2}$ & M. p., ${ }^{\circ} \mathrm{C}$ & Molecular formula & Yield, $\%$ \\
\hline 3.1 & $\mathrm{CH}_{3}$ & $\mathrm{H}$ & $\mathrm{H}$ & $226-228$ & $\mathrm{C}_{12} \mathrm{H}_{14} \mathrm{~N}_{8} \mathrm{O}_{3} \mathrm{~S}$ & 82 \\
\hline 3.2 & $\mathrm{CH}_{3}$ & $\mathrm{H}$ & $\mathrm{NH}_{2}$ & $231-233$ & $\mathrm{C}_{12} \mathrm{H}_{15} \mathrm{~N}_{9} \mathrm{O}_{3} \mathrm{~S}$ & 76 \\
\hline 3.3 & $\mathrm{CH}_{3}$ & $\mathrm{H}$ & $\mathrm{CH}_{3}$ & 202-204 & $\mathrm{C}_{13} \mathrm{H}_{16} \mathrm{~N}_{8} \mathrm{O}_{3} \mathrm{~S}$ & 69 \\
\hline 3.4 & $\mathrm{CH}_{3}$ & $\mathrm{H}$ & $\mathrm{C}_{2} \mathrm{H}_{5}$ & $286-288$ & $\mathrm{C}_{14} \mathrm{H}_{18} \mathrm{~N}_{8} \mathrm{O}_{3} \mathrm{~S}$ & 75 \\
\hline 3.5 & $\mathrm{CH}_{3}$ & $\mathrm{C}_{2} \mathrm{H}_{5}$ & $\mathrm{C}_{2} \mathrm{H}_{5}$ & $217-219$ & $\mathrm{C}_{16} \mathrm{H}_{22} \mathrm{~N}_{8} \mathrm{O}_{3} \mathrm{~S}$ & 78 \\
\hline 3.6 & $\mathrm{CH}_{3}$ & $\mathrm{H}$ & $\mathrm{C}_{2} \mathrm{H}_{4} \mathrm{OH}$ & $265-268$ & $\mathrm{C}_{14} \mathrm{H}_{18} \mathrm{~N}_{8} \mathrm{O}_{4} \mathrm{~S}$ & 81 \\
\hline 3.7 & $\mathrm{CH}_{3}$ & $\mathrm{H}$ & $\mathrm{C}_{6} \mathrm{H}_{4}-4-\mathrm{Br}$ & 197-199 & $\mathrm{C}_{18} \mathrm{H}_{17} \mathrm{BrN}_{8} \mathrm{O}_{3} \mathrm{~S}$ & 64 \\
\hline 3.8 & $\mathrm{C}_{2} \mathrm{H}_{5}$ & $\mathrm{H}$ & $\mathrm{H}$ & $241-243$ & $\mathrm{C}_{13} \mathrm{H}_{16} \mathrm{~N}_{8} \mathrm{O}_{3} \mathrm{~S}$ & 76 \\
\hline 3.9 & $\mathrm{C}_{2} \mathrm{H}_{5}$ & $\mathrm{H}$ & $\mathrm{NH}_{2}$ & 229-231 & $\mathrm{C}_{13} \mathrm{H}_{17} \mathrm{~N}_{9} \mathrm{O}_{3} \mathrm{~S}$ & 77 \\
\hline 3.10 & $\mathrm{C}_{2} \mathrm{H}_{5}$ & $\mathrm{H}$ & $\mathrm{CH}_{3}$ & 214-216 & $\mathrm{C}_{14} \mathrm{H}_{18} \mathrm{~N}_{8} \mathrm{O}_{3} \mathrm{~S}$ & 68 \\
\hline 3.11 & $\mathrm{C}_{2} \mathrm{H}_{5}$ & $\mathrm{H}$ & $\mathrm{C}_{2} \mathrm{H}_{5}$ & 289-291 & $\mathrm{C}_{15} \mathrm{H}_{20} \mathrm{~N}_{8} \mathrm{O}_{3} \mathrm{~S}$ & 80 \\
\hline 3.12 & $\mathrm{C}_{2} \mathrm{H}_{5}$ & $\mathrm{C}_{2} \mathrm{H}_{5}$ & $\mathrm{C}_{2} \mathrm{H}_{5}$ & $233-235$ & $\mathrm{C}_{17} \mathrm{H}_{24} \mathrm{~N}_{8} \mathrm{O}_{3} \mathrm{~S}$ & 73 \\
\hline 3.13 & $\mathrm{C}_{2} \mathrm{H}_{5}$ & $\mathrm{H}$ & $\mathrm{C}_{6} \mathrm{H}_{4}-4-\mathrm{Br}$ & $220-222$ & $\mathrm{C}_{19} \mathrm{H}_{19} \mathrm{BrN}_{8} \mathrm{O}_{3} \mathrm{~S}$ & 69 \\
\hline 3.14 & $\mathrm{C}_{6} \mathrm{H}_{5}$ & $\mathrm{H}$ & $\mathrm{H}$ & $237-239$ & $\mathrm{C}_{17} \mathrm{H}_{16} \mathrm{~N}_{8} \mathrm{O}_{3} \mathrm{~S}$ & 76 \\
\hline 3.15 & $\mathrm{C}_{6} \mathrm{H}_{5}$ & $\mathrm{H}$ & $\mathrm{NH}_{2}$ & 198-200 & $\mathrm{C}_{17} \mathrm{H}_{17} \mathrm{~N}_{9} \mathrm{O}_{3} \mathrm{~S}$ & 83 \\
\hline 3.16 & $\mathrm{C}_{6} \mathrm{H}_{5}$ & $\mathrm{H}$ & $\mathrm{CH}_{3}$ & 232-234 & $\mathrm{C}_{18} \mathrm{H}_{18} \mathrm{~N}_{8} \mathrm{O}_{3} \mathrm{~S}$ & 71 \\
\hline 3.17 & $\mathrm{C}_{6} \mathrm{H}_{5}$ & $\mathrm{CH}_{3}$ & $\mathrm{CH}_{3}$ & 233-235 & $\mathrm{C}_{19} \mathrm{H}_{20} \mathrm{~N}_{8} \mathrm{O}_{3} \mathrm{~S}$ & 75 \\
\hline 3.18 & $\mathrm{C}_{6} \mathrm{H}_{5}$ & $\mathrm{H}$ & $\mathrm{C}_{2} \mathrm{H}_{5}$ & $225-227$ & $\mathrm{C}_{19} \mathrm{H}_{20} \mathrm{~N}_{8} \mathrm{O}_{3} \mathrm{~S}$ & 63 \\
\hline 3.19 & $\mathrm{C}_{6} \mathrm{H}_{5}$ & $\mathrm{H}$ & $\mathrm{C}_{2} \mathrm{H}_{4} \mathrm{OH}$ & 231-233 & $\mathrm{C}_{19} \mathrm{H}_{20} \mathrm{~N}_{8} \mathrm{O}_{3} \mathrm{~S}$ & 86 \\
\hline 3.20 & $\mathrm{C}_{6} \mathrm{H}_{5}$ & $\mathrm{H}$ & $\mathrm{C}_{6} \mathrm{H}_{4}-2-\mathrm{Br}$ & $187-189$ & $\mathrm{C}_{23} \mathrm{H}_{19} \mathrm{BrN}_{8} \mathrm{O}_{3} \mathrm{~S}$ & 64 \\
\hline 3.21 & $\mathrm{C}_{6} \mathrm{H}_{5}$ & $\mathrm{H}$ & $\mathrm{C}_{6} \mathrm{H}_{4}-4-\mathrm{Br}$ & $212-214$ & $\mathrm{C}_{24} \mathrm{H}_{19} \mathrm{~F}_{3} \mathrm{~N}_{8} \mathrm{O}_{3} \mathrm{~S}$ & 67 \\
\hline 3.22 & $\mathrm{C}_{6} \mathrm{H}_{5}$ & $\mathrm{H}$ & $\mathrm{C}_{6} \mathrm{H}_{4}-4-\mathrm{OCH}_{3}$ & 179-181 & $\mathrm{C}_{24} \mathrm{H}_{22} \mathrm{~N}_{8} \mathrm{O}_{4} \mathrm{~S}$ & 76 \\
\hline
\end{tabular}

2-[4-R-5-(3'-methylxanthine-7'-yl)-1,2,4-triazole-3-ylthio] acetic acid, then the corresponding amidated derivatives of 2-[4-R-5-(3'-methylxanthine-7'-yl)-1,2,4-triazole-3ylthio]acetate acid are created. The solvent was evaporated, the residue was crystallized. Interaction of 7'-((3-thio-4R-4H-1,2,4-triazole-5-yl)methyl)-3'-methylxanthine with 2-chloroacetamide in the $\mathrm{NaOH}$ presence leaded to high yielded of corresponding amides (Fig. 1). Hydrazides of 2-[4-R-5-(3'-methylxanthin-7'-yl)-1,2,4-triazole-3-ylthio] acetate acid were synthesized by the reaction of the corresponding esters of 2-[4-R-5-(3'-methylxanthine-7'-yl)1,2,4-triazole-3-ylthio]acetic acid with an aqueous hydrazine hydrate solution in ethanol medium (Fig. 1).

The study of physical-chemical properties of the obtained compounds was carried out using methods listed in the State Pharmacopoeia of Ukraine. Melting points were determined in open capillary tubes in a "Stanford Research Systems Melting Point Apparatus 100" (SRS, USA). The elemental analysis $(\mathrm{C}, \mathrm{H}, \mathrm{N})$ was performed using the "Elementar vario EL cube" analyzer (Elementar Analysensysteme, Germany). IR spectra $\left(4000-400 \mathrm{~cm}^{-1}\right)$ were taken off the module ALPHA-T of Bruker ALPHA FT-IR spectrometer (Bruker optics, Germany). ${ }^{~} \mathrm{H}$ NMR spectra $(400 \mathrm{MHz})$ were recorded at "Varian-Mercury 400 " spectrometer with $\mathrm{SiMe}_{4}$ as internal standard in DMSO- $d_{6}$ solution. Chromatography-mass spectral studies were conducted on the instrument "Agilent 1260 Infinity HPLC" equipped with a mass spectrometer "Agilent 6120 " (method of ionization - electrospray (ESI)).

Amides of 2-[4-R-5-(3'-methylxanthine-7'-yl)-1,2,4-triazole-3-ylthio]acetic acid (Table 1). Method A. To $0.01 \mathrm{~mol}$ of prop-1-yl 2-[4-R-5-(3'-methylxanthin-7'-yl)-1,2,4-triazole3 -ylthio]acetate and $35 \mathrm{ml}$ of propan-1-ol $0.01 \mathrm{~mol}$ ofamine was added, and mixture was heated for 3 hours. Filtrate was cooled, diluted with $50 \mathrm{ml}$ of water. The resulting precipitate was filtered off and recrystallized from 1,4-dioxane (3.3-3.6, $3.10-3.13,3.16-3.19)$ or ethanol $(3.2,3.9,3.15)$. White 

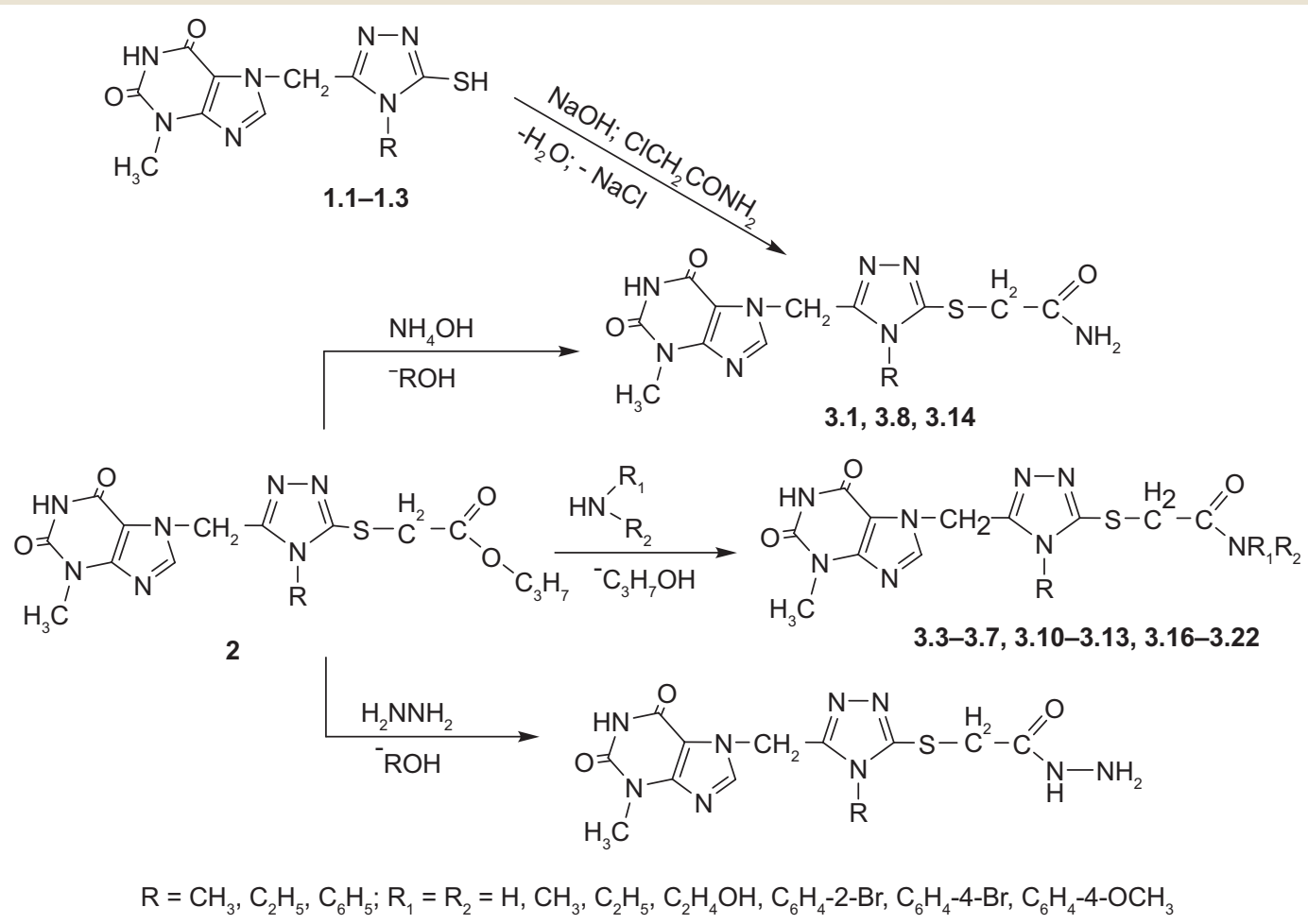

Fig. 1. The scheme of the synthesis of $N$-R-amides and hydrazides of 2-[4-R-5-(3'-methylxanthine-7'-yl)-1,2,4-triazole-3-ylthio]acetic acid.

crystals, slightly soluble in water and alcohols. Method B. A mixture of $0.01 \mathrm{~mol}$ of ester and $10 \mathrm{ml} 25 \%$ aqueous ammonia was refluxed for 12 hours. The obtained solution was evaporated to dryness, the residue was crystallized from ethanol. White crystals, slightly soluble in water and alcohols (3.1, 3.8, 3.14). Method C. To a solution of $0.021 \mathrm{~mol}$ of sodium hydroxide in $40 \mathrm{ml}$ of water $0.02 \mathrm{~mol}$ of 7 '-((4-R-5thio-4H-1,2,4-triazole-3-yl)methyl)theophylline was added. The mixture was stirred until dissolved. Subsequently, 0.02 mol of alkylation agent (2-chloroacetamide, $N$-(2-bromo-phenyl)-2-chloroacetamide, $N$-(4-bromophenyl)-2-chloroacetamide, 2-chloro- $N$-(4-methoxyphenyl)acetamide) in methanol or propan-2-ol was added to the obtained solution. The obtained solution was evaporated to dryness, the residue was crystallized from ethanol. White crystals, slightly soluble in water $(3.1,3.7,3.8,3.13,3.14,3.20-3.22)$.

Hydrazides of 2-[4-R-5-(3'-methylxanthine-7'-yl)-1,2,4triazole-3-ylthio]-acetate acid (Table 1). A mixture of 0.010 mol of the corresponding ester and 0.011 mol of $\mathrm{N}_{2} \mathrm{H}_{4} \cdot \mathrm{H}_{2} \mathrm{O}$ in $50 \mathrm{ml}$ of ethanol was boiled for 1 hour. The resulting precipitate was filtered off, washed with ethanol and dried. White crystalline substances, practically insoluble in water and slightly soluble in alcohols $(3.2,3.9,3.15)$.

Molecular docking. Based on the data obtained through the online service PASS on-line, we have selected compounds for further confirmation of possible activity (anti-inflammation) in silico. Studies were carried out by molecular docking as an approach to the search for molecules with affinity for a specific biological target. As biological targets, we used such macromolecules from Protein Data Bank (PDB): the enzyme COX-2 in combination with indomethacin and celecoxib (PDB ID - 3LN1) [7]. The choice of biological targets is made due to literary data on the mechanism of action of anti-infectious agents [1]. The research methodology consisted of the following stages: 1) preparation of the ligand: construction of structural formulas of compounds using program MarvinSketch 6.3.0 and their preservation in mol-format [8]; generation of 3D structure of compound formulas - molecular modeling (Hyper Chem 8 program using the method of molecular mechanics MM+ and semi-empirical quantum mechanical method PM3, with the maximum number of cycles and Polak-Ribiere algorithm and preservation of molecules in PDB files); use AutoDockTools-1.5.6 to convert PDB - to PDBQT files [9]; 2) preparation of enzymes: removal of water molecules and ligand from a file using the software package Discovery Studio 4.0 and preservation of the enzyme in PDB format [10]; use AutoDockTools-1.5.6 to convert PDB- to PDBQT-files [9]; 3) actual molecular docking: implementation of doking with the program «Vina» with the following spatial parameters of the active center of the enzyme: center_x $=18.37$, center_y $=-52.296$, center_z $=53.949$, size $x=18$, size $y=16$, size $z=16$ for COX-2 (3LN1) [11]; visualization of data using program Discovery Studio 4.0 [10].

\section{Results and discussion}

In the IR-spectra of the obtained compounds, the band of absorption valence of the amide group of primary amides was recorded in the region of $3480-3495 \mathrm{~cm}^{-1}$ and in the range 
Table 2. Affinity ( $\mathrm{kcal} / \mathrm{mol}$ ) of investigated compounds to cyclooxygenase-2

\begin{tabular}{|c|c|c|c|c|c|}
\hline Sub. & $\begin{array}{l}\text { Affinity, (kcal/mol) } \\
\text { to COX-2 (3LN1) }\end{array}$ & Sub. & $\begin{array}{l}\text { Affinity, (kcal/mol) } \\
\text { to COX-2 (3LN1) }\end{array}$ & Sub. & $\begin{array}{l}\text { Affinity, (kcal/mol) } \\
\text { to COX-2 (3LN1) }\end{array}$ \\
\hline 3.1 & -7.7 & 3.8 & -7.7 & 3.15 & -8.2 \\
\hline 3.2 & -7.1 & 3.9 & -7.7 & 3.16 & -7.7 \\
\hline 3.3 & -7.7 & 3.10 & -7.7 & 3.17 & -7.6 \\
\hline 3.4 & -7.6 & 3.11 & -7.7 & 3.18 & -7.7 \\
\hline 3.5 & -6.8 & 3.12 & -7.1 & 3.20 & -8.0 \\
\hline 3.6 & -7.7 & 3.13 & -7.9 & 3.20 & -8.1 \\
\hline 3.7 & -7.9 & 3.14 & -7.7 & Celecoxib & -12.1 \\
\hline
\end{tabular}

$3390-3415 \mathrm{~cm}^{-1}\left(\mathrm{CONH}_{2}\right)$, as well as at $1630-1675 \mathrm{~cm}^{-1}$ $\left(\mathrm{CONH}_{2}\right)$. The absorption bands of the valence fluctuations of secondary amides were recorded in the region of 3135$3310 \mathrm{~cm}^{-1}$. The band of deformation fluctuations of the N-H bond was observed in the range $1605-1621 \mathrm{~cm}^{-1}$.

In the IR-spectrum of hydrazide, an intense absorption band was observed in the region of $1660-1665 \mathrm{~cm}^{-1}$. The band of valence oscillations of the chemical bonds $\mathrm{C}=\mathrm{C}$ and $\mathrm{C}=\mathrm{N}$ involved in conjugation has a frequency of $1620-1625 \mathrm{~cm}^{-1}$.

In ${ }^{1} \mathrm{H}$ NMR spectra of synthesized compounds there are signals of protons with chemical displacements, which confirm the structure of the obtained compounds. Signals of alkyl and aryl protons of the amide residue are observed: methylene groups in the range of 3.75-3.85 ppm, aromatic protons multiplets - for compounds 3.14-3.22 (7.35-8.16 ppm) and the proton of the CONH group (7.05-7.13 ppm). Intense signals of the protons of the methyl group of the xanthine fragment are fixed in the range of 3.35-3.37 ppm, the signals of the methyl group of the triazolum fragment are observed in the region at 3.62-3.66 ppm. The signal of the methine protone of the xanthine fragment is written as a singlet in the region of $8.05-8.12 \mathrm{ppm}$. The protons of the thiomethylene fragment resonates at $3.88-4.00 \mathrm{ppm}$. as a singlet. In compounds 3.20-3.22 the magnetic properties of the protons of the phenyl substituent of the triazole fragment and the aryl fragment of the amide group were so close that their resonance frequencies practically coincided.

In the mass spectrum, there is a peak of the molecular ion and peaks of fragment ions, which confirm this structure.

Based on molecular docking data, it was found that the compounds that were tested for the study are characterized by a moderate level of affinity for the COX-2 enzyme (Table 2).

For one of the compounds with the highest affinity, the complex of the active site of the enzyme COX-2 was visualized and it was established that 2-((5-((3'-methylxanthin-7'-yl) methyl)-4-phenyl-4H-1,2,4-triazol-3-yl)thio)acetohydrazides are characterized by the formation of hydrogen bonds of the second Nitrogen atom of the triazole fragment and the Sulfur atom of the $-\mathrm{S}-\mathrm{CH}_{2}-\mathrm{C}(\mathrm{O})$-fragment with the amino acid residues TYR341 and ARG106 respectively.

The comparable values of the scoring functions of the reference preparations and the compound under study indicate the thermodynamic probability and energy favorability of the formation of complexes between the molecule of the substance under study and the specified receptor.

\section{Conclusions}

A universal method for the preparation of $N$-R-amides and hydrazides of 2-[4-R-5-(3'-methylxanthine-7'-yl)-1,2,4-triazole-3-ylthio] acetic acid were developed. It was established that reaction product yield of the interaction of the starting thiol with 2-chloroacetamide is greater than that of the reaction of the corresponding ester with ammonia.

Prospects for further research. According to the research results it is planned to expand the line of this class of compounds to identify promising biologically active compounds among them.

\section{Funding}

The research is carried out within the SRW of Zaporizhzhia State Medical University "Synthesis of new biologically active substances derivatives of 4-R- (amino)-1,2,4-triazolyl-3-thione 5-(alkyl-, aryl-, heteryl) derivatives for the creation of original drugs with analgesic, actoprotective, antimicrobial, diuretic and anti-inflammatory action" state registration number 0115 U003470 (2015-2017).

\section{Фінансування}

Дослідження виконане в рамках НДР Запорізького державного медичного університету «Синтез нових біологічно активних речовин похідних 5-(алкіл-, арил-, гетерил-) похідних 4-R-(аміно)-1,2,4-тріазоліл3-тіонів для створення оригінальних лікарських засобів з аналгетичною, актопротекторною, антимікробною, діуретичною та протизапальною дією» № держреєстрації 0115U003470 (2015-2017).

Conflicts of interest: author has no conflict of interest to declare. Конфлікт інтересів: відсутній.

Information about author:

Hotsulia A. S., PhD, Associate Professor, the Department of Toxicology and Inorganic Chemistry, Zaporizhzhia State Medical University, Ukraine.

\section{Відомості про автора:}

Гоцуля А. С., канд. фрарм. наук, доцент каф. токсикологічної та неорганічної хімії, Запорізький державний медичний університет, Україна.

Сведения об авторе:

Гоцуля А. С., канд. фарм. наук, доцент каф. токсикологической и неорганической химии, Запорожский государственный медицинский университет, Украина. 


\section{References}

[1] Anshul, C., \& Amanpreet, K. (2014) Extensive study on microwave assisted synthesis of monocyclic heterocyclic compounds. International journal of universal pharmacy and bio sciences, 3(1), 133-135.

[2] Bechara, W. S., Khazhieva, I. S., Rodriguez, E., \& Charette, A. B. (2015) Synthesis of 3,4,5-trisubstituted 1,2,4-triazoles via the addition of hydrazides to activated secondary amides. Org. Lett., 17(5), 1184-1187. doi: 10.1021/acs.orglett.5b00128.

[3] Chenglu, Zhang, Huan, Xi, Yuting, Sha, Xiaona, Sun, Chuanyin, Li, Jing, Wang, \& Yizheng, Li. (2017) Synthesis and bioactivity of novel bis-heterocyclic amide modified sulfide derivatives. Chinese Journal of Applied Chemistry, 34(3), 308-315. doi: 10.11944/j.issn.10000518.2017.03.160352.

[4] El-Wahab, H., Hamdy, A. -R. M., Gamal-Eldin, S. A., \& El-Gendy, M. A. (2011) Synthesis, biological evaluation and molecular modeling study of substituted 1,2,4-triazole-3-acetic acid derivatives. Der Pharma Chemica, 3(6), 540-552.

[5] Franklim, T. N., Freire-de-Lima, L., Diniz, J., Previato, J., Castro, R., Mendonça-Previato, L., \& Lima, M. (2013) Synthesis and trypanocidal evaluation of novel 1,2,4-triazoles-3-thiones derived from natural piperine. Molecules, 18, 6366-6382. doi: 10.3390/molecules18066366.

[6] Pachuta-Stec, A., Kosikowska, U., Chodkowska, A., Pitucha, M., Malm, \& A., Jagiełło-Wójtowicz, E. (2012) Biological activity of novel $\mathrm{N}$-substituted amides of endo-3-(3-methylthio-1,2,4-triazol-5-yl)bicyclo[2.2.1] hept-5-ene-2-carboxylic acid and $\mathrm{N}$-substituted amides of 1-(5-methylthio-1,2,4-triazol-3-yl)cyclohexane-2-carboxylic acids. Z. Naturforsch, 67, 123-128. doi: 10.5560/ZNC.2012.67c0123.
[7] Ruping, T., Linhong, J., Mou, C., Yin, J., Bai, S., Hu, D., et al. (2015) Synthesis, antifungal and antibacterial activity for novel amide derivatives containing a triazole moiety. Chemistry Central Journal, 7, 30 . doi: 10.1186/1752-153X-7-30.

[8] Sydorenko, L. V., Ukrainets, I. V., \& Alieksieieva, T. B. (2009) Syntez ta vyvchenia antymikobakterialnoi aktyvnosti monoftorbenzylamid 1-R-4-hidroksy-2-okso-1,2-dyhidrokhinolin-3-karbonovykh kyslot [The synthesis and study of the antimycobacterial activity of monofluorobenzylamides of 1-R-4-hydroxy-2-oxo-1,2-dihydroquinoline-3-carboxylic acids]. Visnyk farmatsii, 2(58), 12-15. [in Ukrainian].

[9] Ukrainets, I. V., Sydorenko, L. V., Horokhova, O. V., et al. (2004) Syntez, budova ta protytuberkulozni vlastyvosti N-R-amidiv1-tsyklopropil-2-okso-4-hidroksy-1,2,5,6,7,8-heksahidrokhinolin-3-karbonovi kysloty [Synthesis, structure and anti-tuberculosis properties of $\mathrm{N}$-R-amides 1-cyclopropyl-2-oxo-4-hydroxy-1,2,5,6,7,8-hexahydroquinoline-3-carboxylic acid]. Visnyk farmatsii, 2(38), 7-12. [in Ukrainian].

[10] Ukrainets I. V., Sidorenko L. V., Horokhova O. V. (2004) Syntez, budova ta protytubercuberculozni vlastyvosti $N$-R-amidiv 1 -tsyklopropil-2-okso-4-hidroksy-1,2,5,6,7,8-heksahidrohinolin-3-karbonovikysloty. Visnyk farmatsii, 2(38): 7-12. [in Ukrainian].

[11] Vikas, G. R., Kiran, G., \& Vinayak, D. (2014) Synthesis, characterization and study of some $\mathrm{N}$-substituted aryl-2-(\{4-[(substituted Aryl carbamoyl)methyl]-5-(pyridin-4-yl)-4H-1,2,4-triazol-3-yl\}sulfanyl) acetamide. Iranian Journal of Pharmaceutical Sciences, 10(2), 21-34. 